\title{
Talent Management and Talent Building in Upgrading Employee Performance
}

\author{
Naif Fawzi Alruwaili ${ }^{1}$
}

\begin{abstract}
This study has three objectives. The first one seeks to determine the distinction between innate and acquired talent in relation to performance. The second objective identifies best practices in talent management that can be used by a company's Human Resources Department (HRD). The third objective highlights activities of current employees that can be used to benchmark them as able to become talented. This study was conducted in Saudi Arabian companies operating in the Al Jouf and Northern Border Provinces. Therefore, the researcher recommends further research on companies operating outside these two provinces. A qualitative approach was used to collect data by conducting face to face semi-structured interviews with the heads of HR departments in companies in the AlJouf and Northern Border provinces area of the Kingdom of Saudi Arabia. Results show that talent management can be a strategic plan for organizations to improve their performance.
\end{abstract}

Keywords: Talent Management, Human Resource Management, HR Practices, Employee Performance.

\section{Introduction}

Talent Management (TM) simply means that there are talented people who have joined an organization. The work of Human Resource Management (HRM) is to refine and adapt this talent to achieve the goals of the organization. However, there are employees in any organization who have the willingness to become talented.

The TM process begins with HRM practices, starting with recruitment and selection practices. There are several differences between the concept of talent management and talent building. A direct supervision feature can discover the talented employee and recommend them to the HR department in order to allow them to acquire new skills, knowledge and experience. They will be trained in HR practices in order to achieve the ultimate goal of performance improvement.

Based on the literature, the emergence of TM as a human resource management (HRM) activity was the result of tremendous developments in the world of business. These developments include technology, communications, e-commerce, etc. Therefore, organizations are now more concerned with acquiring human capital that can deal with these developments efficiently, seeking to recruit and employ people with the skills, knowledge and multi-experiences to achieve organizational innovation and excellence. However, the question that arises here is: what is the real role of the HRM department in relation to talent? More specifically, previous research has dealt with the role of the HRM department in talent management, but has ignored the fact that talent in the world of business could be acquired. 
This study focuses on analyzing the differences in HRM practices towards managing existing talent compared with building talent, which can be viewed as being similar to knowledge, as it is classified as explicit and tacit knowledge (Kikoski \& Kikoski, 2004, p.67) and talent could be innate or acquired. Therefore, the HRM department in any organization is dealing with two types of talent: one of which needs to be managed, and the other needs to be built. Therefore, the main research question of this study can be stated as follows:

"Is there a difference in the mandated human resource management practices depending on the type of talent?"

The answer to this question requires answers to several other related questions, the most important of which are: Is there a link between HRM practices and talent management? What are the main practices followed by an HRM department in term of talented people? How can the HRM department identify features among the existing employees who have the potential to become talented? What are the differences between talent management and talent building?

By answering the above questions, this study will achieve many important objectives for other researchers and organizations in terms of determining the differences between innate and acquired talent; identifying the critical practices in talent management for those who are already talented; and shedding light on the practices that are aimed at discovering those who have the willingness and ability to become talented from among existing employees.

\section{Why is talent management important?}

In the era of globalization and economic and cultural openness, organizations are facing significant challenges arising originally from the intensification of competition in most of their activities. In addition to competition in product quality and price, expanding into new locations around the world, and accessing new markets, it has become necessary for organizations to own human capital that is capable to rise to these challenges.

The significance of this study consists in the fact that organizations must attract and hire people who have the ability to create new ideas, advance work methods, and innovate. The related literature points out that good talent management will attract more talented individuals and increase retention in the organization (Christensen Hughes \& Rog, 2008).

\section{Theoretical framework and literature review}

\subsection{What are talent and talent management?}

The term "talent" is related mostly to individuals. Morton (2004) defined talent as those employees who have an endogenous capacity that enables them to make substantial and desirable changes in the current and future performance of the organization. Other researchers have defined talent as multiple competencies that should be developed to allow an individual to practice a certain role in an excellent manner (González-Cruz, Martínez-Fuentes, \& Pardo-del-Val, 2009, p.22). Therefore, organizations are now seeking to attract and employ such individuals through winning the war for talent (Ulrich \& Smallwood, 2012). In order to win this war, it is essential for the management of human resources in the organization to exercise practices that have become known as "Talent Management". TM can be defined as systematic efforts aimed at identifying talented individuals and their locations in order to attract them to work in 
the organization. Furthermore, the HRM should work to develop these talents and retain them in order for that talent to be deployed within the organization (Scullion, Collings \& Caligiuri, 2010). Morton (2005, p.13) considered TM as a multifaceted concept that has been adopted by the practitioners of HRM because this adoption is a necessary weapon in the war for talent. TM may be seen by these practitioners as a form of organizational mindset or culture that creates a feeling among the staff that they are of real value in the organization.

\subsection{Types of talent}

TM has received a lot of attention from academics and practitioners, which explains the large number of researchers in this field, such as Lewis and Heckman (2006), Morton (2004) and Pfeffer (2001). However, few researchers have compared innate and acquired talent. In this context Meyers, van Woerkom and Dries (2013) pointed out that the talent management system in an organization should distinguish between talent management practices according to the origin of this talent. In order to do this, any HRM taking a decision about pursuing talent management or talent building has to ask the following question: Is talent predominantly an innate construct, is it majority acquired, or does it result from the interaction between certain levels of nature and nurture components? Silva (2006) reported that an individual who is innately talented can master several tasks, while the person who has no innate talent can learn and master one task in a time period and, step by step, master other skills. Thus, talent management needs less time and effort than talent building.

Based on what has been stated above, we conclude that innate talent-holders can be managed by the organization through exploiting their talent within the scope of its work and operations. An employee talented in dealing with figures, for example, can be enrolled upon a training course on financial analysis and then rehired in the financial section of the organization soon afterwards and at relatively little expense. The employee who was selected to be talented through talent imparted in a certain field will take a longer time and involve a higher cost to achieve this goal. This process may involve several stages. First, in the "selection stage", the HR department could hold a talent test for a number of employees, using an IQ test to select one or more of them (Shuttleworth-Edwards et al., 2004) by asking questions such as: What is the number that does not belong to the following numerical series? $30,128,12,7,6$ ? If the sales volume now is $\$ 12,000$ and the company is thinking to increase the selling price per unit by $5 \%$, what are the expected probabilities of this action?

In the second stage, the HR department will select the employees who passed the test and provide them with suitable training for their new jobs, which is why this will take longer and cost more.

\section{Talent building versus practices of talent management}

In this section, the analysis requires differentiation between three types of employee. First, we should acknowledge that an HRM department will work to recruit talented new graduates, who form the first type of employee. The recruiter might coordinate with a university to collect data about graduates who have innate talent in 
order to recruit the best from among them. In this regard, Qian (2010) pointed out that a university is more likely to be able to identify talented graduates. After recruiting and selecting those employees who have inmate talent, the orientation stage will be very important in the TM of this type of employee. Sparrow and Budhwar (1997) reported that employee orientation is a significant tool in TM because it works as a form of spiritual orientation, while Gull and Doh (2004) pointed out that when an organization adopts a culture of talent, this will encourage employees to bring out their talents. This means that people in charge in the HRM department should encourage the impression in a new employee that he/she will work in a talent environment. Moreover, training for this type of employee will not take a long time because their talents enable them to understand the work techniques and rules fully, as well as the tasks needed for their jobs. Some researchers favor on-the-job training for this category of employee. In this regard, Markman and Baron (2003) suggested that this kind of training will lead talented trainees to reveal and propose opportunities to the organization that may be exploited in finding new ventures.

The second category of employees represents those who are already working in the organization and have innate talent but are not recognized for two reasons: the employee does not have the opportunity to show his/her talents because of the routine working style in the organization, and the organization will not appreciate his/her talent in terms of providing incentives. However, nowadays, and in response to the rapid developments in the business world, the HR department in an organization will move to create talented employees who are capable of meeting these developments and have the ability and willingness to achieve organizational goals. This requires to bring holders of innate talent out within the organization and work to refine their talent by training, learning and rehabilitation, which will give opportunities for employees to use their capacities and creative talents.

In addition to HR department practices in the field of TM (e.g., training, learning, rehabilitation, and motivation), employee empowerment can be an effective tool in this respect, because it involves encouraging and developing the skills for self-sufficiency (Besterfield, 2003, p.96). The relationship between the talent management of the previous categories of employees and employee empowerment lies in excellent managerial talent, which is increasingly perceived as scarce and expensive.

However, empowerment enables managerial talent to be focused more on external changes and less on internal problem solving (Srivastava \& Bhatnagar, 2007). Empowerment may also reveal sources of managerial talent which were previously unrecognized and create circumstances in which such talent can flourish. This leads to staff no longer being prepared to accept the old command and control systems. Employee retention will be supported by empowerment in addition to an incentive system (Hill \& Huq, 2004, pp. 1025-1041).

The third category of employees includes those who have no innate talent. This category can be talented people in their jobs through intensive training by talented staff that leads the trainees to feel jealous. 


\section{Methodology}

A qualitative approach was used in this study by conducting face to face semistructured interviews with the heads of HR departments in companies operating in the Al Jouf and Northern Border areas of the Kingdom of Saudi Arabia. The purpose of the interview questions was to identify the practices of HR departments in relation to talent management and talent building, and how these departments chose employees who could become talented through providing the opportunity for them to acquire an upgrade. Therefore, the interviews consisted of two categories of questions: the first concerned TM, and the second related to talent building. The objectives of these questions were to explore the actual practices implemented by the HRM departments in these companies in the field of TM and talent building among the employees, in order to evaluate the extent of the companies' success in this crucial aspect. It should then be possible to identify administrative gaps which prevent the application of the successful management of talent in order to provide guidance and advice to the management of human resources in the company and correct its course in this respect. The researcher follows an ontological research philosophy, which claims that all people view a phenomenon in the same domain (Bryman \& Bell, 2015).

\subsection{Data collection}

A purposive sample technique was selected by the researcher in order to collect qualitative primary data through face to face semi-structured interviews. Purposive sampling is practical and can be used to study the experiences of knowledgeable experts (Tongco, 2007). The implementation of a semi-structured interview technique involved twenty HR managers and specialists working in companies (both public and private) in the Al-Jouf and Northern Borders Provinces of Saudi Arabia. The distribution of these managers allowed the involvement in the research of a number of companies from different sectors, such as banking, industry and education. Secondary data were collected from related literature, including research, books and journal articles.

As mentioned earlier, two types of questions were used to explore HR practices in relation to TM and talent building. The questions in the first set were framed as follows: Do you agree that talent management is one of the HRM practices which is linked with all HRM practices? Does the talent management process start with employee recruitment? What are the main practices followed in your company to manage talent? What is the role of supervisors in the talent management process? Can you give a brief description of the role of training in talented employees' retention? The second group of questions was as follows: How can you identify an employee who has the willingness to acquire talent? Is the strategy of the company in this area sustainable or according to a timetable?

\subsection{Data analysis}

The answers given by the interviewees were recorded by notes in order to conduct a thematic analysis through the use of NVivo software. This kind of analysis is used for qualitative data and depends on coding interviewees' responses according to consistent answers. Thematic analysis can provide a full understanding of complex phenomena (Smith \& Firth, 2011).

According to Braun and Clarke (2006), thematic analysis provides very detailed and broad data. The steps in the analysis process include coding and re-reading data by 
labeling themes that are covered by the research variables and research questions and identified from the interview transcripts to provide appropriate answers to the research questions. The coding process is aimed at the systematic research of indicators that reflect the diverse perceptions which represent the preferences, understandings, and behaviors practiced by the people who were interviewed (Bryman \& Bell, 2007).

\section{Findings}

\section{Talent management is linked to HRM practices and the process starts with employee recruitment}

All the interviewees were convinced that TM is a core and major link in HRM practices achieving the company's goals, such as employee performance. Most of the interviewees agreed that the recruitment process is the starting point in the journey of TM, whereby the recruiter plays an essential role in attracting talented individuals through coordination with universities and employment agencies. This idea is supported by Cappelli (2008, p.9), who maintained that organizations should make links between internal development and external recruitment to fill their talent pool.

\section{Main practices for managing talent}

With regard to HR practices in TM, the answers of the interviewees were mostly compatible in terms of directing talent towards achieving organizational goals through training and the transfer of polished talent to the workplace, while good training works to give talented employees skills and knowledge that will develop a spirit of creativity and innovation in these individuals. Buckingham and Vosburgh (2001, p.17) pointed out that, as one of the HR practices, training aims to maximize the talent of employees. One of the interviewees added the role of incentives to this issue because these may achieve talent retention. Park (2014) stated that talented employees are one of the valuable assets in an organization that need to be directed and controlled. Therefore, the interviewees mostly agree that employees need HR practices that increase their talent and retention by applying a motivation strategy.

\section{Supervisors' role in talent management}

Regarding the role of supervisors, the interviewees moderately agreed that the supervisor has a main role in TM because he/she is able to direct talent towards performance improvement. Someone with the means to discover the ability and willingness of an employee to acquire talent can recommend him/her to the HR department, but this role in the field of TM is often a complementary one to the practices of HRM in terms of exploiting the talent itself in the workplace. Evidence for this trend has been discussed by Farley (2005), in which he states that supervisors' reporting includes talented employees' data and their relationships with good performance.

\section{Talent management and talent building}

The responses in this regard have mostly agreed on the definitions of TM and talent building which assume that there are talented employees in the organization, and that the HR department should work to polish this talent through training and directing it towards performance improvement. Another category of employees in the organization are those who have a real willingness to acquire talent, hence talent building. Moreover, the interviewees also indicated that the strategy of talent building is sustainable, although one of them stated that his company has no strategy for this task. 


\section{Talent management strategy}

The researcher noted that the private companies involved in the research were, in general, working to develop a sustainable strategy for talent management, while the public companies did not have such an approach. One of the respondents attributed this state to the high rate of employee turnover in public companies (Christensen Hughes \& Rog, 2008).

\section{Discussion}

In general, TM was expressed in the literature as a task that goes along with HRM practices starting by the systematic attraction of desired individuals through identification of their talent's validity to meet the organization needs (Thunnissen, 2016). Accordingly, this attraction is the first stage of talent management by HR department in the organization (Dries, 2013).

Some authors reported that the systematic recruitment is adopted mostly in the private sector more than the public sector. In this regard, Smeenk. et al, (2007) pointed out the Dutch universities have shifted from a collegial system to manage the recruitment and employment, to a developed managerial system that was trialed in private sector. And this is in line with the outcome of this study, related to the TM strategy. The findings of this study indicate that training was a key instrument to polish and direct talents for the benefit of achieving the company's goals.

Thunnissen (2016) suggested that employees with innate talent may benefit much more from discussion meetings with colleagues and cooperating with a team of researchers than benefit from organized training courses. Meyers. et al, (2013) pointed out that organizations should focus strongly on recruitment, identification and retention when dealing with innate talent holders. However, when dealing with employees who want to acquire talent, the HRM department should focus mainly on employees training and development in terms of providing new knowledge and skills. Furthermore, this study found that the supervisor has an important role in talent management in terms of directing talent towards performance development, and discovering employees who have the ability and willingness to be talents, in this regard McCall (2010) pointed out that supervisors should provide the opportunities to show one's talent in the workplace.

In order to reflect the view stated in the literature, and to be sure of the consistency of these views with the findings, the researcher stipulated the following:

This research was conducted to investigate how Saudi companies were practicing TM. The study sample consisted of companies operating in Al-Jouf and Northern Border. Two types of talent have been taken into consideration in the study: innate talent and acquired talent. In this regard Silva (2006) pointed out that there are two types of individuals in the business world: the individual who is innately creator in many fields, and the individual who struggles to acquire skills. All the interviewees have confirmed this issue because the existing employees in their companies include the two categories of employees.

In addition to that, they stated that the best recruitment methods may help the company in hiring talented applicants among university graduates as a main source of young talent (Guthridge et al., 2008). So, this innate talent must be directed and trained so that to 
exploit it in the interest of the organization, as well as to stimulate talented employees and retain them.

Talent building depends heavily on the cooperation between the supervisors and the HR department, where the supervisor shall recommend the employees who are willing to acquire talent, while the human resources management shall work on their rehabilitation and training for this purpose, and this is consistent with Besterfield's (2003) view on the role of rehabilitation and training in this aspect.

\section{Conclusion}

Talent management in the environment of most organizations is global, and highly competitive. In addition, most organizations are now seeking to recruit and employ people with the skills, knowledge and multi-experiences to achieve organizational innovation and excellence. The review of the literature and this study's sample (companies' employees) have equally revealed a strong interest in the new area of talent management. In this paper, we attempted to determine talent management and talent building of employee performance, and practices of human resources department in companies. This research also sheds light on practices aimed at finding out existing talented employees. Our research framework highlights the importance of talent management and the different types of talented employees in term of performance and the implementation of HR practices.

Research findings on the main practices of talent management indicate that through training and supervision the company's performance can be improved and employees can be encouraged to discover their talent and improve it. Moreover, the best recruitment methods may help the company in hiring talented applicants among university graduates. Besides, most companies -especially those in the private sector- are committed to talent management as part of the organization's strategy.

Consequently, there is a strong need for theory building related to talent management so that to understand the relationship between talent management and HRM activities. The performance of companies will improve if more empirical studies on the attraction and retention of talented employees are put to practice, and thus bridging the gap of knowledge transfer from academics to HR.

\section{References}

Besterfield, D.H. (2003). Total Quality Management, Prentice Hall.

Braun, V. and Clarke, V. (2006) Using thematic analysis in psychology. Qualitative Research in Psychology, 3 (2). pp. 77-101.

Bryman, A. and Bell, E. (2007). Business Research Methods (2nd ed.). New York: $\quad$ Oxford University Press. Bryman, A. and Bell, E. (2015). Business Research Methods (4th ed.). New York: Oxford University Press.

Buckingham, M. and Vosburgh, R.M. (2001). The 21 st_Century Human Resources Function: It's the Talent, Stupid! Human Resource Planning, 24(4): 17-21.

Cappelli, P. (2008). Talent Management for the Twenty-First Century. Harvard Business Review, 86(3): 74-81.

Christensen Hughes, J.C. and Rog, E. (2008). Talent Management: A Strategy for Improving Employee Recruitment, Retention and Engagement within Hospitality Organizations. International Journal of Contemporary Hospitality Management, 20(7): 743-757. 
Farley, C. (2005). HRS Role in Talent Management and Driving Business Results. Employment Relations Today, 32(1): 55-61.

González-Cruz, T., Martínez-Fuentes, C., and Pardo-del-Val, M. (2009). Cited in Gallardo-Gallardo, E., Dries, N., and González-Cruz, T.F. (2013). What is the Meaning of 'Talent' in the World of Work? Human Resource Management Review, 23(Dec.): 290-300.

Gull, G. and Doh, J. (2004). The Transmutation of the Organization: Toward a More Spiritual Workplace. Journal of Management Inquiry, 13(2): 128-139.

Guthridge, M., Komm, A.B., and Lawson, E. (2008). Making Talent a Strategic Priority. The Mckinsey Quarterly, Number 1.

Hill, F. and Huq. R. (2004). Employee Empowerment: Conceptualizations, Aims and Outcomes. Journal of Total Quality Management, 15(8): 1025-1041.

Kikoski, C.K. and Kikoski, J.F. (2004). The Inquiring Organization: Tacit Knowledge, Conversation and Knowledge Creation Skills for 21st-Century Organizations. Westport, CT and London: Praeger.

Lewis, R.E. and Heckman, R.J. (2006). Talent Management: A Critical Review. Human Resources Management Review, 16(2): 139-154.

McCall, M. (2010). Recasting Leadership Development. Industrial and Organizational Psychology,3(1): 3-19.

Markman, G.D. and Baron, R.A. (2003). Person-Entrepreneurial Fit: Why Some People are More Successful as Entrepreneurs than Others. Human Resources Management Review, 13(2): 281-301.

Meyers, C., van Woerkom, M., and Dries, N. (2013). Talent - Innate or Acquired?Theoretical Considerations and their Implications for Talent Management. Human Resource Management Review, 23: 305-321.

Morton, L. (2004). Integrated and Integrative Talent Management: A Strategic HR Framework, Research Report R-134504-RR. New York: Conference Board.

Morton, L. (2005). Talent Management Value Imperatives: Strategies for Successful Execution, Research Report R-136005-RR. New York: Conference Board.

Park, J. (2014). Retaining Talented Employees in the Hotel Industry in Stavanger: An Interview-Based Qualitative Research. University of Stavanger, Norway.

Pfeffer, J. (2001). Fighting the War for Talent is Hazardous to your Organization's Health. Organizational Dynamics, 29(4): 248-259.

Qian, H. (2010). Talent, Creativity and Regional Economic Performance:The Case of China. The Annals of Regional Science, 45(1): 133-156.

Scullion, H., Collings, D.G., and Caligiuri, P. (2010). Global Talent Management. Journal of World Business, 45(3): 105-108.

Smeenk, R. M., Verwaal, V. J. and Zoetmulder, F. A. N. (2007), Learning curve of combined modality treatment in peritoneal surface disease. BrJ Surg, 94: 1408-1414.

Shuttleworth-Edwards, A.B., Kemp, R.D., Rust, A.L., Muirhead, J.G., Hartman, N.P., and Radloff, S.E. (2004). Cross-cultural Effects on IQ Test Performance: A Review and Preliminary Normative Indications on WAIS - III Test Performance. Journal of Clinical and Experimental Neuropsychology, 26(7): 903-920.

Silva, O. (2006). The Jack-of-All-Trades Entrepreneur: Innate Talent or Acquired Skill? Discussion Paper No. 2264. Bonn, Germany: Institute for the Study of Labour (IZA).

Smith, J. and Firth, J. (2011). Qualitative Data Analysis: The Framework Approach. Nurse Researcher, 18(2): 52-62.

Sparrow, P.R. and Budhwar, P.S. (1997). Competition and Change: Mapping the Indian HRM Recipe Against World-Wide Patterns. Journal of World Business, 32: 224-242.

Srivastava, P. and Bhatnagar, J. (2007). Talent Acquisition Due Diligence Leading to High Employee Engagement: Case of Motorola India MDB. Presented at the Asia Pacific Researchers in Organizational Studies (APROS) 12 Conference, held 9-12 December at the Management Development Institute (MDI), Gurgaon, India.

Subotnik, R. and Rickoff, R. (2010). Should Eminence Based on Outstanding Innovation be the Goal of Gifted Education and Talent Development? Implications for Policy and Research. Learning and Individual Differences, 20(4): 358-364.

Thunnissen, M. (2016). Talent Management for What, How and How Well? An empirical exploration of talent management in practice. Employee Relation, 38(1): 57-72.

Tongco, M.D. (2007). Purposive Sampling As a Tool for Informant Selection. Ethnobotany Research \& Applications, 5(1): 147-158.

Ulrich, D. and Smallwood, N. (2012). What is Talent? Leader to Leader, 63: 55-61. 